\title{
FACTORS ASSOCIATED WITH THE QUALITY OF CARE IN THE EMERGENCY UNIT, AT NAIBONAT HOSPITAL, KUPANG, EAST NUSA TENGGARA
}

\author{
Antonia Nogo'), Chris Oiladang'), Ina Debora Ratu Ludji3) \\ ${ }^{1)}$ Kupang District Health Office, East Nusa Tenggara \\ 2)Masters Program in Public Health, Nusa Cendana University \\ 3) School of Health Polytechnics, Ministry of Health, Kupang
}

\begin{abstract}
Background: Quality healthcare is a production of cooperation between the patient and the healthcare provider in a supportive environment. Personal factors of the provider and the patient, and factors pertaining to the healthcare organization, healthcare system, and the broader environment, affect healthcare service quality. This study aimed to analyze factors associated with the quality of care in the emergency unit at Naibonat Hospital, Kupang, East Nusa Tenggara.

Subjects and Method: This was a cross sectional study conducted at Naibonat Hospital, Kupang, East Nusa Tenggara. A sample of 170 patients and 30 health workers consisting doctors, nurses, and staff, were selected for this study. The dependent variable was quality of service. The independent variables were performance, motivation, response time, and discipline. The data were collected by questionnaire and analyzed by a multiple logistic regression.

Results: Work performance $(\mathrm{OR}=7.47 ; 95 \% \mathrm{CI}=1.40$ to $39.84 ; \mathrm{p}=0.019)$, strong motivation $(\mathrm{OR}=6.19 ; 95 \% \mathrm{CI}=0,019$ to $4.02 ; \mathrm{p}=0.045)$, quick response $(\mathrm{OR}=$ $6.56 ; 95 \% \mathrm{CI}=1.26$ to $34.20 ; \mathrm{p}=0.026)$, and discipline $(\mathrm{OR}=7.47 ; 95 \% \mathrm{CI}=1.40$ to $39.84 ; \mathrm{p}=0.019$ ) of the health workers were associated with better quality of health services.

Conclusion: Quality of health services is associated with good work performance, strong motivation, quick response, and discipline, of the health workers.
\end{abstract}

Keywords: quality, health service, work performance, motivation, response time, discipline, health workers, hospital

\section{Correspondence:}

Antonia Nogo. Kupang District Health Office, East Nusa Tenggara, Indonesia. Email Address: antonianogoo805@gmail.com. Mobile: 082236111008. 